\title{
FAKTOR - FAKTOR YANG MEMPENGARUHI STUNTING PADA BALITA DI KABUPATEN GROBOGAN
}

\author{
Yuwanti ${ }^{1}$, Festy Mahanani Mulyaningrum ${ }^{2}$, Meity Mulya Susanti ${ }^{3}$ \\ ${ }^{1-3}$ Universitas An Nuur \\ Email: yuwanti84@gmail.com
}

\begin{abstract}
ABSTRAK
Stunting pada anak merupakan masalah gizi yang menjadi masalah nasional, hal ini dikarenakan stunting berdampak negatif terhadap sumber daya manusia di masa yang akan datang. Riset Kesehatan Dasar tahun 2013 menunjukkan prevalensi stunting masih sejumlah 37, 2\%. Sirkesnas tahun 2016 mencatat bahwa prevalensi stunting mencapai 33,6\%, hal ini menjadi masalah kesehatan yang penting dikarenakan masalah stunting berada diatas ambang batas $20 \%$. Sedangkan Stunting pada anak balita disebabkan oleh multifaktor seperti konsumsi gizi selama hamil, pengetahuan ibu tentang gizi, akses pelayanan yang terbatas, akses sanitasi dan kebersihan air yang kurang memadai. Dampak stunting yaitu penurunan kecerdasan, kerentanan terhadap penyakit, menghambat pertumbuhan ekonomi dan produktifitas kerja dan memperburuk kesenjangan. Stunting pada balita dimana tinggi badan lebih pendek dari usia pada umumnya. Penelitian ini bertujuan untuk mengetahui faktor - faktor yang mempengaruhi kejadian stunting pada balita di Kabupaten Grobogan. Penelitian ini merupakan penelitian kuantitatif dengan pendekatan cross - sectional. Populasi penelitian yaitu seluruh kasus stunting pada balita di wilayah Kabupaten Grobogan. Pengambilan sampel penelitian dilakukan secara purposive sampling. Data penelitian di analisa menggunakan SPSS for window, untuk analisa data bivariat menggunakan uji Chi Square, sedangkan data multivariat menggunakan uji Regresi Logistik. Hasil penelitian diketahui bahwa status gizi, masalah kesehatan pada anak, kebiasaan makan makanan instan, dan tinggi badan ibu berhubungan dengan stunting pada balita dengan nilai $\mathrm{p}$ value $<0,05$. Pantang makanan, riwayat konsumsi tablet besi, riwayat antenatal care, riwayat penyakit penyerta dalam kehamilan, riwayat pemberian ASI ekslusif, sanitasi air bersih, lingkungan perokok dan kondisi ekonomi tidak berhubungan dengan kejadian stunting pada balita dengan $\mathrm{p}$ value $=>0,05$. Status gizi, tinggi badan ibu, dan kebiasaan makan makanan instan secara bersama- sama sebagai faktor resiko kejadian stunting pada balita. Kesimpulan dari penelitian ini yaitu status gizi, masalah kesehatan pada anak, kebiasaan makan makanan instan, dan tinggi badan ibu berhubungan dengan stunting pada balita
\end{abstract}

Kata Kunci: Stunting, balita, gizi

\section{ABSTRACT}

Stunting in children is a national problem, this is because stunting negatively impacts human resources in the future. Basic Health Research in 2013 showed the prevalence of stunting was still 37, $2 \%$. Sirkesnas in 2016 noted that the prevalence of stunting reached $33.6 \%$, this is an important health issue because the problem of stunting is above the $20 \%$ threshold. While stunting in toddlers is caused by multifactors such as nutrition consumption during pregnancy, maternal knowledge about nutrition, limited access to services, access to sanitation and inadequate water hygiene. The impact of stunting is a decrease in intelligence, susceptibility to disease, inhibiting economic growth and productivity of work and exacerbating inequality. Stunting in toddlers where height is shorter than the general age. This study aims to find out the factors that influence stunting events in toddlers in Grobogan Regency. This research is quantitative research with a cross-sectional approach. The research population is the entire case of stunting in toddlers in grobogan regency area. Research sampling is conducted purposive sampling. Research data in analysis using SPSS for window, for bivariate data analysis using Chi Square test, while multivariate data using Logistics Regression test. 
The results found that nutritional status, health problems in children, instant food eating habits, and maternal height were associated with stunting in toddlers with a $p$ value of $<0.05$. Abstinence from food, history of iron tablet consumption, antenatal care history, history of infectious diseases in pregnancy, history of exclusive breastfeeding, sanitation of clean water, smoker's environment and economic conditions not related to stunting events in toddlers with $p$ value $=>0.05$. Nutritional status, maternal height, and instant food eating habits together as risk factors for stunting in toddlers. The conclusions of this study are nutritional status, health problems in children, instant food eating habits, and maternal height associated with stunting in toddlers

Keywords: Stunting, toddler, nutrition 


\section{LATAR BELAKANG}

Stunting ( balita pendek) di Indonesia merupakan masalah gizi yang masih menjadi prioritas, hal ini karena permasalahan gizi berdampak pada kualitas sumber daya manusia (SDM). Prevalensi stunting dari Riset Kesehatan Dasar Tahun 2013 sejumlah 37,2\%, sedangkan hasil pencatatan status gizi tahun 2016 sebesar 27,5 \% jauh lebih besar dibandingkan dengan batasan WHO $<20 \%$. Hal ini berarti bahwa terjadi masalah pertumbuhan tidak maksimal pada 8,9 juta anak Indonesia atau 1 dari 3 anak mengalami stunting. Stunting merupakan kondisi dimana tinggi badan seseorang lebih pendek dari usia umumnnya (Kemendesa, 2017).

Stunting disebabkan oleh masalah asupan gizi yang dikonsumsi selama kandungan maupun masa balita. Kurangnya pengetahuan ibu mengenai kesehatan dan gizi sebelum masa kehamilan, serta masa nifas, terbatasnya layanan kesehatan seperti pelayanan antenatal, pelayanan post natal dan rendahnya akses makanan bergizi, rendahnya akses sanitasi dan air bersih juga merupakan penyebab stunting.

Multi faktor yang sangat beragam tersebut membutuhkan intervensi yang paling menentukan yaitu pada 1000 HPK ( 1000 hari pertama kehidupan ). Faktor Penyebab stunting juga dipengaruhi oleh pekerjaan ibu, tinggi badan ayah, tinggi badan ibu, pendapatan, jumlah anggota rumah tangga, pola asuh, dan pemberian ASI eksklusif (Wahdah, Juffrie, \& Huriyati, 2015), selain itu stunting juga disebabkan oleh beberapa faktor lain seperti pendidikan ibu, pengetahuan ibu mengenai gizi, pemberian ASI eksklusif, umur pemberian MP-ASI, tingkat kecukupan zink dan zat besi, riwayat penyakit infeksi serta faktor genetik. (Aridiyah, Rohmawati, \& Ririanty, 2015)

Prevalensi stunting di Indonesia berdasarkan Riskesdas tahun 2018 mengalami penurunan sekitar 7,2 \% dari 37, $2 \%$ prevalensi stunting secara Nasional tahun 2017 namun angka ini masih dibawah target yang di tetapkan oleh WHO yaitu dibawah $20 \%$. Prevalensi stunting di Jawa Tengah memberikan kontribusi sebanyak $28 \%$ dan menduduki peringkat 9 dari seluruh propinsi di Jawa Tengah 2018 meskipun data ini lebih baik jika dibandingkan dengan tahun 2016 yang menduduki peringkat 13. Kabupaten Grobogan sebagai salah satu provinsi dengan angka stunting yang besar hingga dalam pada tahun 2017 ada beberapa wilayah yang masuk dalam 1.000 desa prioritas penanganan stunting.

Stunting pada balita memberikan dampak yang besar terhadap kesehatan anak untuk masa sekarang maupun masa mendatang. Stunting dan masalah gizi lainnya dapat dicegah terutama pada 1.000 hari pertama kehidupan dan upaya lain seperti Pemberian makanan tambahan, dan fortifikasi zat besi pada bahan pangan.

\section{METODE PENELITIAN}

Jenis penelitian ini adalah penelitian korelasi dengan pendekatan cross sectional. Penelitian dilakukan di wilayah Kabupaten Grobogan, dengan populasi balita stunting usia 0 - 59 bulan. Jumlah sampel dalam penelitian ini 90 orang. Analisis data bivariat menggunakan Chi Square dan analisis data multivariat menggunakan Regresi logistik.

\section{HASIL DAN PEMBAHASAN}

Berdasarkan hasil analisis univariat diketahui Jumlah responden balita stunting sebanyak 90 orang dengan status sangat pendek sebanyak 26 orang (28,9\%), dan pendek sejumlah 64 orang $(71,1 \%)$. Usia balita yang menjadi responden $0-5$ tahun dengan jenis kelamin perempuan sejumlah 44 orang ( $48,9 \%$ ), dan berjenis kelamin laki-laki sejumlah 46 orang ( $51,1 \%)$. Status gizi responden diketahui gizi buruk sejumlah 17 orang $(18,9 \%)$, gizi kurang sejumlah 16 orang ( 17,8$)$, dan gizi baik sejumlah 57 orang ( $63,3 \%)$. Jumlah responden dengan ibu yang memiliki tinggi badan $\leq 150 \mathrm{~cm}$ sejumlah 44 orang $(48,(\%)$, dan responden 
dengan ibu yang memiliki tinggi badan $\geq 151 \mathrm{~cm}$ sejumlah 46 orang ( $51,1 \%)$. Jumlah responden dengan riwayat ibu mengkonsumsi tablet Fe sejumlah 79 orang ( 87,8\%), sedangkan responden dengan riwayat ibu yang tidak mengkonsumsi Fe sejumlah 11orang ( $12,2 \%$ ). Jumlah responden yang memiliki riwayat melakukan Antenatal care 87 orang ( $96,7 \%)$, sedangkan yang tidak melakukan antenatal care sejumlah 3 orang ( $3,3 \%)$. Jumlah responden yang memiliki ibu dengan penyakit penyerta dalam kehamilan 14 orang (15,6\%), dan responden yang tidak memilki riwyat penyakit penyerta dalam kehamilan sejumlah 76 orang $(84,4 \%)$, jumlah responden yang memiliki riwayat pemberian ASI ekslusif sejumlah 64 orang ( 71,1), dan tidak diberikan ASI Ekslusif sejumlah 26 orang ( 28,9\%). Jumlah responden dengan masalah kesehatan pada anak sejumlah 51 orang ( 56,7\%), dan yang tidak memiliki masalah kesehatan sejumlah 39 orang (43,3\%). Jumlah responden yang memiliki kebiasaan makan makanan instan sejumlah 37 orang $(41,1 \%)$, dan yang tidak ada kebiasaan makan makanan instan sejumah 53 orang $(58,9 \%)$. Jumlah responden dengan kepemilikan dan pemanfaatan pekarangan sejumlah 37 orang (41,1\%), sedangkan tidak memilkiki dan tidak memanfaatkan pekarangan sejumlah 53 orang ( 58,9\%). Jumlah responden dengan kepemilikan sumber air bersih sejumlah 87 orang (96,7\%), sedangkan yang tidak memilki sumber air bersih sejumlah 3 orang (3,3\%). Jumlah responden yang tinggal dengan lingkungan perokok sejumlah 66 orang ( 73,3\%), sedangkan tidak tinggal dalam lingkungan perokok sejumlah 26,7\%. Jumlah responden dengan keluarga ekonomi cukup sejumlah 29 orang $(32,2 \%)$, sedangkan jumlah responden dengan ekonomi kurang sejumlah 61 orang $(67,8 \%)$.

Tabel 1

Hubungan faktor - faktor yang mempengaruhi stunting pada balita.

\begin{tabular}{|c|c|c|c|c|c|c|c|}
\hline & & & & & & & \\
\hline & & San & endek & & & & \\
\hline & & $\mathrm{N}$ & $\%$ & $\mathrm{~N}$ & $\%$ & $d f$ & $\mathrm{p}$ value \\
\hline Status gizi & & & & & & & \\
\hline & Gizi buruk & 16 & 94,10 & 1 & 5,90 & & \\
\hline & Gizi kurang & 8 & 50,00 & 8 & 50,00 & 2 & 0.000 \\
\hline & Gizi baik & 2 & 3,50 & 55 & 96,50 & & \\
\hline
\end{tabular}

Masalah kesehatan anak

\begin{tabular}{rcccccc} 
Ada & 21 & 41,20 & 30 & 58,80 & 1 & 0.004 \\
Tidak & 5 & 12,80 & 34 & 87,20 & & \\
\hline
\end{tabular}

Tarak/pantang makanan

\begin{tabular}{rcccccc} 
Ada & 8 & 25,00 & 24 & 75,0 & \multirow{2}{*}{0.631} \\
Tidak & 18 & 31,00 & 40 & 69,0 & & \\
\hline
\end{tabular}

Kebiasaan makan makanan instan

\begin{tabular}{rcrrrrr} 
Ada & 18 & 46,60 & 19 & 51,40 & 1 & 0.001 \\
Tidak & 8 & 15,10 & 45 & 84,90 & & \\
\hline
\end{tabular}

Tinggi badan Ibu

\begin{tabular}{lcccccc}
$<150 \mathrm{~cm}$ & 19 & 43,20 & 25 & 56,80 & 1 & 0.003 \\
$>151 \mathrm{~cm}$ & 7 & 15,20 & 39 & 84,80 & & \\
\hline
\end{tabular}




\begin{tabular}{|c|c|c|c|c|c|c|c|}
\hline \multicolumn{8}{|c|}{ Konsumsi Fe } \\
\hline & Tidak mengkonsumsi & 1 & 9,10 & 10 & 90,90 & \multirow{2}{*}{1} & \multirow{2}{*}{0.166} \\
\hline & Mengkonsumsi & 25 & 31,60 & 54 & 68,40 & & \\
\hline \multicolumn{8}{|c|}{ Riwayat ANC } \\
\hline & Tidak ada & 0 & 0,00 & 3 & 100,00 & \multirow{2}{*}{1} & \multirow{2}{*}{0.554} \\
\hline & Ada & 26 & 29,00 & 61 & 70,10 & & \\
\hline \multirow{4}{*}{$\begin{array}{l}\text { Riwayat } \\
\text { kehamilan }\end{array}$} & Penyakit dalam & & & & & & \\
\hline & Ada & & & & & & \\
\hline & Tidak ada & 6 & 42,90 & 8 & 57,10 & \multirow{2}{*}{1} & \multirow{2}{*}{0.217} \\
\hline & & 20 & 26,30 & 56 & 73,70 & & \\
\hline \multirow{3}{*}{$\begin{array}{l}\text { Riwayat } \\
\text { ekslusif }\end{array}$} & Pemberian asi & & & & & & \\
\hline & Tidak diberikan & 15 & 57,70 & 11 & 42,30 & \multirow{2}{*}{1} & \multirow{2}{*}{0.000} \\
\hline & Diberikan & 11 & 17,20 & 53 & 82,80 & & \\
\hline \multicolumn{8}{|c|}{$\begin{array}{l}\text { Pemanfaatan pekarangan } \\
\text { rumah }\end{array}$} \\
\hline & Tidak dimanfaatkan & 8 & 33,30 & 16 & 17,10 & \multirow{2}{*}{1} & \multirow{2}{*}{0.605} \\
\hline & Dimanfaatkan & 18 & 27,30 & 48 & 72,70 & & \\
\hline \multicolumn{8}{|c|}{ Kepemilikan sumber air bersih } \\
\hline & Tidak mempunyai & 1 & 33,30 & 2 & 66,70 & \multirow{2}{*}{1} & \multirow{2}{*}{1.000} \\
\hline & Mempunyai & 25 & 28,70 & 62 & 71,30 & & \\
\hline \multicolumn{8}{|c|}{ Lingkungan perokok } \\
\hline & Ya & 20 & 30,30 & 46 & 69,70 & \multirow{2}{*}{1} & \multirow{2}{*}{0,794} \\
\hline & Tidak & 6 & 25,00 & 18 & 75,00 & & \\
\hline \multicolumn{8}{|c|}{ Ekonomi keluarga } \\
\hline & Kurang & 23 & 37,70 & 38 & 62,300 & \multirow{2}{*}{1} & \multirow{2}{*}{0.06} \\
\hline & Cukup & 3 & 10,30 & 36 & 89,700 & & \\
\hline
\end{tabular}

Berdasarkan tabel diatas dapat diketahui bahwa pada stunting pada anak balita diketahui berhubungan dengan status gizi anak, riwayat masalah kesehatan pada anak, kebiasaan makan makanan instan, dan riwayat dalam pemberian ASI eskslusif, dan tinggi badan ibu dengan nilai $\mathrm{P}$ value $<0,05$. Hasil penelitian ini juga diketahui bahwa tarak atau tidak makan makanan tertentu, riwayat ibu yang mengkonsumsi tablet besi selama kehamilan, riwayat ibu yang melakukan pemeriksaan antenatal care, kepemilikan dan pemanfaatan pekarangan untuk menanam berbagai sayur dan buah, kepemilikan sumber air bersih, lingkungan tinggal dengan perokok dan kondisi ekonomi keluarga tidak berhubungan dengan stunting pada anak balita.

Berdasarkan kriteria variabel independen yang memiliki nilai $\mathrm{p}<0,25$ antara lain status gizi pada anak, riwayat pemberian Asi ekslusif, masalah kesehatan pada anak, kebiasaan makan makanan instan, Tinggi badan ibu, Riwayat konsumsi tablet Fe, Riwayat penyakit penyerta selama hamil, dan ekonomi keluarga. 
Tabel 2

Analisis Multivariat Faktor -faktor resiko yang mempengaruhi stunting balita

\begin{tabular}{lccccc}
\hline \multicolumn{1}{c}{ Variabel } & B & SE & p Value & OR & $95,00 \%$ \\
\hline Status gizi & -4.677 & 2.041 & 0,022 & 0,009 & $0,000-0,508$ \\
\hline Tinggi badan ibu & -3.303 & 1.334 & 0,013 & 0,037 & $0,003-0,502$ \\
\hline Riwayat Konsumsi Fe & 4.589 & 2.803 & 0,102 & 98.444 & $0,405-23934$ \\
\hline $\begin{array}{l}\text { Riwayat penyakit penyerta } \\
\text { kehamilan }\end{array}$ & -0.925 & 1.683 & 0,583 & 0,397 & $0,015-10,749$ \\
\hline Pemberian ASI Ekslusif & -3.562 & 1.961 & 0,069 & 0,028 & $0,001-1,326$ \\
\hline $\begin{array}{l}\text { Masalah kesehatan pada } \\
\text { Anak }\end{array}$ & -1.000 & 1.455 & 0,492 & 0,368 & $0,021-6,370$ \\
\hline $\begin{array}{l}\text { Kebiasaan Makan makanan } \\
\text { Instan }\end{array}$ & -2.964 & 1.391 & 0,033 & 0,052 & $0,003-0789$ \\
\hline Ekonomi Keluarga & -1.070 & 1.441 & 0,458 & 0,343 & $0,020-5781$ \\
\hline
\end{tabular}

Berdasarkan data diatas dapat disimpulkan bahwa status gizi balita dengan $p$ value 0,022 $<0,05$ berarti status gizi berhubungan dengan kejadian stunting pada balita, dan nilai Odd Ratio sebesar 0,009 berarti status gizi menjadi faktor resiko terjadinya stunting. Tinggi badan ibu diketahui mempunyai nilai $\mathrm{p}$ value $=0,013<0,05$, dengan nilai $\mathrm{OR}=0,037$ berarti bahwa tinggi badan ibu merupakan faktor resiko terjadinya stunting dan beresiko 0,037 kali lebih besar dibandingkan pada tinggi badan ibu yang $>151 \mathrm{~cm}$. Kebiasaan makan makanan instan mempunyai nilai $\mathrm{p}$ value $=0,033$ dengan OR 0,052 , dengan demikian bahwa kebiasaan anak dalam mengkonsumsi makanan instan merupakan faktor yang berpengaruh pada kejadian balita stunting, dan memiliki resiko 0,052 kali lebih besar dibandingkan dengan anak yang tidak memiliki kebiasaan makan makanan instan. Hasil penelitian juga menunjukkan bahwa paritas, Riwayat konsumsi tablet Fe, Riwayat penyakit penyerta dalam kehamilan, Riwayat pemberian ASI ekslusif, dan pendapatan keluarga tidak berhubungan dengan kejadian stunting pada balita, dan juga bukan sebagai faktor resiko yang menyebabkan stunting.

\section{Status Gizi balita}

Pengamatan penelitian ini dilakukan terhadap balita stunting sebanyak 90 balita. Hasil pengamatan statistik diketahui bahwa status gizi merupakan faktor yang berhubungan dan beresiko terdahap kejadian stunting pada balita. status gizi balita. Stunting (kerdil) merupakan kondisi dimana balita memiliki panjang atau tinggi badan yang kurang jika dibandingkan dengan umur. kondisi ini diukur dengan menghitung panjang atau tinggi badan yang lebih dari minus 2 standar deviasi median standar pertumbuhan anak dari WHO (Kementerian Kesehatan RI, 2018). Hasil penelitian diketahui bahwa status gizi balita dengan $\mathrm{p}$ value $=0,022<0,05, \mathrm{OR}=0,009$, hal ini berarti bahwa status gizi balita mempengaruhi terjadinya stunting dan menjadi faktor resiko stunting pada balita. Hasil penelitian ini sejalan dengan penelitian yang dilakukan oleh Mugiyati, dkk (2018) bahwa asupan konsumsi energi berhubungan dengan kejadian stunting. Asupan gizi yang tidak adekuat akan mempengaruhi pertumbuhan fisik pada anak (Mugianti, Mulyadi, Khoirul, \& Najah, 2018) .Status gizi pada anak sebagai salah satu tolak ukur dalam penilaian kecukupan asupan gizi harian dan 
penggunaan zat gizi untuk kebutuhan tubuh. jika asupan nutrisi anak terpenuhi dan dapat digunakan seoptimal mungkin maka pertumbuhan dan perkembangan anak akan menjadi optimal, dan sebaliknya apabila status gizi anak bermasalah maka akan mempengaruhi pertumbuhan dan perkembangan anak hingga dewasa.

\section{Masalah kesehatan anak}

Hasil analisis bivariat diketahui bahwa masalah kesehatan pada anak diketahui nilai $\mathrm{p}$ value $=$ $0,004<0,05$ dapat diketahui bahwa masalah kesehatan pada anak berhubungan dengan kejadian stunting pada balita, meskipun demikian dalam analisis multivariat masalah kesehatan pada anak bukan sebagai faktor resiko terjadinya stunting. Hasil penelitian ini sejalan dengan penelitian yang dilakukan oleh Aridiyah, dkk ( 2015) bahwa penyakit infeksi berhubungan dengan kejadian stunting pada anak balita yang berada di pedesaan maupun perkotaan (Aridiyah et al., 2015). Masalah kesehatan pada anak yang paling sering terjadi adalah masalah infeksi seperti diare, infeksi saluran pernafasan atas, kecacingan dan penyakit lain yang berhubungan dengan gangguan kesehatan kronik. Masalah kesehatan anak dapat mengganggu pertumbuhan dan perkembangan dikarenakan intake makanan menurun, menurunnya absorbsi zat gizi oleh tubuh yang menyebabkan tubuh kehilalangan zat gizi yang dibutuhakan untuk pertumbuhan dan perkembangan. Masalah kesehatan yang berlanjut menyebabkan imunitas tubuh mengalami penurunan, sehingga mempermudah terjadinya penyakit atau infeksi. Kondisi yang demikian apabila terjadi secara terus menerus maka dapat menyebabkan gangguan gizi kronik yang akan menyebabkan gangguan pertumbuhan seperti stunting.

\section{Pantang makanan}

Hasil penelitian diketahui bahwa kebiasaan tarak/pantang makanan tertentu diketahui bahwa nilai $\mathrm{p}$ value $=0,631$ dapat disimpulkan bahwa tarak / pantang makanan tertentu tidak berhubungan dengan kejadian stunting pada balita. Tarak / pantang makanan tertentu yang dikonsumsi anak memang seharusnya dilakukan hal ini karena tidak semua makanan baik dan sehat untuk anak. Beberapa makanan yang dikonsumsi anak dapat menyebabkan alergi, muntah, atau tersedak. Beberapa makanan yang tidak diajurkan untuk dikonsumsi seperti makanan yang bersoda yang apabila dikonsumsi dalam jangka waktu lama dapat menyebabkan masalah kesehatan, makanan yang mengandung bahan pengawet dan kadar gula gula tinggi juga dapat meningkatkan berbagai resiko kesehatan pada anak, hal ini diperkuat dengan penelitian yang dilakukan oleh Laili, dkk (2008) bahwa intake makanan dan ketahanan pangan dalam keluarga mempengaruhi kejadian stunting pada anak dibawah lima tahun (Ayik Nikmatul Lailli, Al Munawar, 2018).

\section{Kebiasaan makan makanan instan}

Hasil penelitian analisis bivariat kebiasaan makan makanan instan diketahui nilai $\mathrm{p}$ value $=$ 0,001 yang berarti bahwa kebiasaan makan makanan instan berhubungan dengan kejadian stunting pada balita, selain itu hasil analisis multivariat diketahui bahwa nilai $\mathrm{p}$ value $=0,033$ dengan $\mathrm{OR}=0,052$ dengan demikian kebiasan makan makanan instan pada anak beresiko pada kejadian stunting 0,052 lebih besar dibandingkan dengan anak yang tidak memiliki kebiasan makan makanan instan. Makanan instan merupakan makanan yang mudah dalam hal pengolahan, namun demikian makanan instan mengandung kalori yang tinggi, serta mengandung kadar gula, lemak dan garam yang tinggi. Makanan instan apabila dikonsumsi 
dalam waktu yang lama akan meningkatkan berat badan yang mengarah kepada obesitas pada anak, makanan instan juga meningkatkan resiko diabetes tipe 2 dikarenakan kandungan kalori dan lemak tinggi yang mampu meningkatkan lonjakan gula darah dalam tubuh. Anak yang sering mengkonsumsi makanan instan dapat meningkatkan kerusakan gigi, serta gangguan pada pernafasan akibat obesitas, dan resiko kanker. Meskipun makanan instan justru meningkatkan obesitas, tetapi bukan berarti bahwa asupan gizi mikro dan makro bagi pertumbuhan dan perkembangan pada anak, sehingga pertumbuhannya tidak sesuai dengan usia. Hal ini diperkuat dengan penelitian yang dilakukan oleh Payab, dkk (2015) bahwa konsumsi junk food meningkatkan dan beresiko secara umum pada kejadian obesitas (Payab et al., 2015).

\section{Tinggi badan ibu}

Analisis bivariat menunjukkan $\mathrm{p}$ value $=0,003$ dapat diketahui bahwa tinggi badan ibu berhubungan dengan kejadian stunting, selain itu pada analisis multivariat diketahui bahwa nilai $\mathrm{OR}=0,037$ dapat disimpulkan bahwa tinggi badan ibu beresiko 0,037 kali lebih besar pada kejadian stunting. Hasil penelitian ini sejalan dengan penelitian yang dilakukan oleh Amin dan Julia (2014) bahwa tinggi badan orang tua berkaitan dengan kejadian stunting pada anak, terutama pada ibu yang memiliki tinggi badan $<150$, dimana ibu yang pendek beresiko melahirkan anak yang stunting 1,98 kali lebih besar dibandingkan dengan tinggi badan yang normal. (Nur Afia Amin, 2014)

\section{Konsumsi Tablet besi}

Hasil analisis bivariat pada riwayat konsumsi tablet besi diketahui nilai $\mathrm{p}$ value $=0,166$ dengan demikian riwayat konsumsi tablet besi selama kehamilan tidak berhubungan dengan kejadian stunting pada balita. Meskipun demikian perbaikan gizi pada ibu hamil dengan pemberian tablet besi minimal 90 tablet selama kehamilan sangat penting diberikan selain untuk memelihara kesehatan ibu juga digunakan untuk kebutuhan kecukupan besi selama kehamilan yang dipergunakan untuk pertumbuhan dan perkembangan janin. Pemberian tablet besi juga merupakan salah satu program pemerintah dalam upaya menurunkan angka stunting yang diprogramkan oleh Kementerian desa, pembangunan daerah tertinggal dan transmigrasi (Kemendesa, 2017).

\section{Riwayat Antenatal}

Riwayat antenatal care dalam penelitian ini tidak berhubungan dengan kejadian stunting, hal ini diketahui dari hasil analisis bivariat dimana $\mathrm{p}$ value $=0,554$. Hasil penelitian ini tidak sejalan dengan penelitian yang dilakukan oleh Najanah, dkk (2013) bahwa kunjungan antenatal tidak standar berhubungan dan beresiko mempunyai balita stunting 2,4 kali lebih besar dibandingkan dengan ibu yang melakukan ANC standar (Najahah, Adhi, Ngurah, \& Pinatih, 2013).. Pelayanan kesehatan masa hamil bertujuan untuk memenuhi hak setiap ibu hamil memperoleh pelayanan kesehatan yang berkualitas sehingga mampu menjalani kehamilan yang sehat, bersalin, dengan selamat dan melahirkan bayi yang sehat dan berkualitas. Pelayanan antenatal dilakukan semasa konsepsi hingga mulainya proses persalinan, dan dilaksanakan sekurang - kurangnya 4 kali selama masa kehamilan (Kementrian Kesehatan RI, 2014) 


\section{Penyakit penyerta dalam kehamilan}

Hasil analisis data dalam penelitian ini diketahui $\mathrm{p}$ value $0,217<0,005$, maka dapat disimpulkan bahwa penyakit yang menyertai kehamilan tidak berhubungan dengan kejadian stunting pada balita, meskipun demikian deteksi dini penyakit yang menyertai kehamilan diperlukan melalui program pemeriksaan antenatal care ditujukan untuk upaya menjaga kelangsungan hidup ibu dan janin, serta upaya untuk menurunkan morbiditas maupun mortalitas bagi ibu maupun janin.

\section{Pemberian ASI ekslusif}

Hasil penelitian ini diketahui bahwa pemberian ASI Ekslusif dengan kejadian stunting dengan $\mathrm{p}$ Value $=0,000<0,05$ berarti bahwa pemberian Asi ekslusif berhubungan dengan kejadian stunting pada balita, meskipun demikian ternyata ASI ekslusif bukan sebagai faktor resiko terjadinya stunting berdasarkan analisis data multivariat $p$ value $=0,069$. Hasil penelitian sejalan dengan Ni'mah dan Nadhiroh tahun 2015 dimana balita yang tidak mendapatkan ASI Ekslusif selama 6 bulan pertama lebih tinggi pada kelompok balita stunting dibandingkan dengan kelompok balita normal, dan diketahui terdapat hubungan antara pemberian Asi ekslusif dengan kejadian stunting (Ni'mah \& Nadhiroh, 2015). Hasil penelitian ini juga sejalan dengan penelitian Rahmad dan Miko (2016) bahwa tidak memberikan ASI ekslusif menyebabkan terjadinya stunting pada balita di Banda Aceh, sekaligus bahwa tidak memberikan ASI Ekslusif menjadi faktor dominan sebagai penyebab resiko anak mengalami stunting (Rahmad \& Miko, 2016)

\section{Pemanfaatan pekarangan}

Berdasarkan hasil penelitian diketahui bahwa keluarga yang memanfaatkan pekarangan rumah untuk menanam berbagai sayur dan buah dengan analisis bivariat diketahui nilai $\mathrm{p}$ value $=0,605$, hal ini berarti bahwa pemanfaatan pekarangan tidak berhubungan dengan kejadian stunting pada balita. pemanfataan pekarangan rumah diharapkan mampu meningkatkan ketahanan pangan dalam keluarga dan juga sebagai salah satu sumber pangan yang beragam untuk pemenuhan gizi terutama sayur dan buah yang memiliki kandung mineral dan vitamin yang diperlukan dalam masa pertumbuhan dan perkembangan anak.

\section{Kepemilikan sumber air bersih}

Hasil penelitian diketahui bahwa kepemilikan sumber air bersih di dalam keluarga dengan nilai $\mathrm{p}$ Value $=1,000$ yang berarti tidak ada hubungan bermakna antara kepemilikan sumber air bersih dengan kejadian stunting anak balita. hasil penelitian ini tidak sejalan dengan penelitian Desyanti dan Nindya (2017) dimana praktik higiene yang buruk menjadi faktor resiko terhadap kejadian stunting sebesar 4,808 kali lebih besar (Al-Rahmad et al, 2013). Kepemilikan sumber air bersih dalam keluarga berkaitan dengan sanitasi sumber air bersih dan sehat, dimana konsumsi sumber air yang bersih dan sehat akan mengurangi resiko kejadian penyakit yang disebabkan oleh diare atau kecacingan, namun demikian dalam penelitian ini terbukti tidak ada hubungan dengan kejadian stunting karena ada berbagai banyak faktor yang berpengaruh seperti status gizi anak dan tinggi badan ibu.

\section{Lingkungan perokok}


Hasil penelitian diketahui bahwa lingkungan perokok tidak berhubungan dengan kejadian stunting pada anak, hal ini berbeda dengan temuan bahwa anak anak yang tinggal di rumah tangga dengan orang tua perokok kronis serta transien cenderung memiliki pertumbuhan lebih lambat dalam berat dan tinggi dibandingkan mereka yang tinggal di rumah tangga tanpa perokok. Anak yang tinggal dlingkungan perokok dapat menyebabkan gangguan dalam penyerapan gizi karena asap rokok, dan orang tua yang merokok mengurangi besaran biaya belanja yang seharusnya dapat digunakan untuk pembelian makanan yang bergizi, biaya kesehatan dan pendidikan anak.

\section{Kondisi ekonomi keluarga}

Hasil penelitian diketahui bahwa pada kondisi ekonomi analisis bivariat nilai $\mathrm{p}$ value $=0.06$ < 0,05 , pada analisis multivariat diketahui bahwa kondisi ekonomi dengan nilai $\mathrm{p}$ value $=0,458$ $\mathrm{OR}=0,343$, hal ini berarti bahwa kondisi ekonomi tidak berhubungan dan bukan sebagai faktor resiko terjadinya stunting pada balita. pendapatan atau kondisi ekonomi keluarga yang kurang biasanya akan berdampak kepada hal akses terhadap bahan makanan yang terkait dengan daya beli yang rendah, selain itu apabila daya beli rendah maka mungkin bisa terjadi kerawanan pangan di tingkat rumah tangga. (Kementerian Kesehatan RI, 2018) Hasil berbeda didapatkan dari penelitian Rahmad dan Miko ( 2016) yang menyimpulkan bahwa pendapatan keluarga yang rendah berhubungan dengan stunting pada balita di Banda Aceh. (Rahmad \& Miko, 2016)

\section{SIMPULAN DAN SARAN Simpulan}

Penelitian ini dapat disimpulkan bahwa status gizi, masalah kesehatan pada anak, kebiasaan makan makanan instan, dan tinggi badan ibu berhubungan dengan stunting pada balita. Pantang makanan, riwayat konsumsi tablet besi, riwayat antenatal care, riwayat penyakit penyerta dalam kehamilan, riwayat pemberian ASI ekslusif, sanitasi air bersih, lingkungan perokok dan kondisi ekonomi tidak berhubungan dengan kejadian stunting pada balita. Status gizi, tinggi badan ibu, dan kebiasaan makan makanan instan secara bersamasama sebagai faktor resiko kejadian stunting pada balita.

\section{Saran}

Berdasarkan hasil penelitian ini disarankan bahwa perlu adanya edukasi kepada calon orang tua dan orang tua untuk melakukan pemantauan terhadap pertumbuhan dan perkembangan anak balitanya.

\section{UCAPAN TERIMAKASIH}

Ucapan terimakasih kepada Deputi Bidang Penguatan Penguatan Riset dan Pengembangan kepada Kemeterian Riset dan Teknologi/ Badan Riset dan Inovasi Nasional.

\section{DAFTAR PUSTAKA}

Al-Rahmad et al. (2013). Kajian Stunting Pada Anak Balita Ditinjau dari Pemberian Asi Eksklusif, Mp-Asi, Status Imunisasi Dan Karakteristik Keluarga di Kota Banda Aceh Stunting Study on Children Viewed From Exclusive Breast Feeding, Complementary Breastfeeding, Immunization S. Jurnal Kesehatan Ilmiah Nasuwakes, 6(2), 169-184.

Aridiyah, F. O., Rohmawati, N., \& Ririanty, M. (2015). Faktor-faktor yang Mempengaruhi

Kejadian Stunting pada Anak Balita di Wilayah Pedesaan dan Perkotaan (The Factors 
Affecting Stunting on Toddlers in Rural and Urban Areas). E-Jurnal Pustaka Kesehatan, 3(1), 163-170.

Ayik Nikmatul Lailli, Al Munawar, F. W. (2018). Food Intake and Food Security as

Determinants of Stunting Children Under Five Years. Health Nations, 2(1), 25-32.

Kemendesa. (2017). Buku Saku Desa dalam Penanganan Stunting. Jakarta.

Kementerian Kesehatan RI. (2018). Pusdatin : buletin stunting. Kementerian Kesehatan RI, 1, 2.

Kementrian Kesehatan RI. Peraturan Menteri Kesehatan Republik Indonesia Nomor 97 Tahun 2014 (2014). https://doi.org/10.1300/J064v05n01_12

Mugianti, S., Mulyadi, A., Khoirul, A., \& Najah, Z. L. (2018). Faktor penyebab anak Stunting usia 25-60 bulan di Kecamatan Sukorejo Kota Blitar. Jurnal Ners Dan Kebidanan, 268-278. https://doi.org/10.26699/jnk.v5i3.ART.p268

Najahah, I., Adhi, K. T., Ngurah, G., \& Pinatih, I. (2013). Risk factors of stunting for 12-36 month old children in Dasan Agung Public Health Centre, Mataram , West Nusa Tenggara Province Faktor risiko balita stunting usia 12-36 bulan di Puskesmas Dasan Agung , Mataram , Provinsi Nusa Tenggara Barat, 1(2), 103-108. https://doi.org/10.15562/phpma.v1i2.171

Ni'mah, K., \& Nadhiroh, S. R. (2015). Faktor yang Berhubungan dengan Kejadian Stunting pada Balita. Media Gizi Indonesia, 10(1), 13-19.

Nur Afia Amin, M. J. (2014). Faktor sosiodemogra fi dan tinggi badan orang tua serta hubungannya dengan kejadian stunting pada balita usia 6-23 bulan. Jurnal Gizi Dan Diabetik Indonesia, 2(3), 170-177.

Payab, M., Kelishadi, R., Qorbani, M., Motlagh, M. E., Ranjbar, S. H., Ardalan, G., ... Heshmat, R. (2015). Association of junk food consumption with high blood pressure and obesity in Iranian children and adolescents: the Caspian-IV Study. Jornal de Pediatria (Versão Em Português), 91(2), 196-205. https://doi.org/10.1016/j.jpedp.2014.07.008

Rahmad, A. H. AL, \& Miko, A. (2016). Kajian Stunting Pada Anak Balita Berdasarkan Pola Asuh dan Pendapatan Keluarga di Kota Banda Aceh. Jurnal Kesmas Indonesia, 8(2), 63-79.

Wahdah, S., Juffrie, M., \& Huriyati, E. (2015). Faktor risiko kejadian stunting pada Anak umur 6 - 36 Bulan di Wilayah Pedalaman Kecamatan Silat Hulu, Kapuas Hulu, Kalimantan Barat. Jurnal Gizi Dan Dietetik Indonesia, 3(2), 119-130. 